\title{
Conditions for the Reproduction of Human Capital in a Sustainable City on the Example of Krasnodar
}

\author{
Eleanor Chernenko ${ }^{1, *}$, Inna Lebedeva ${ }^{2}$, Victoriya Kupina ${ }^{2}$ \\ ${ }^{1}$ Krasnodar Branch of Plekhanov Russian University of Economics, Krasnodar, Russia \\ ${ }^{2}$ Kuban State Medical University, Community Health, Healthcare and History of Medicine Department, Krasnodar, \\ Russia \\ *Corresponding author. Email: 79184814276@yandex.ru
}

\begin{abstract}
Ideally, a sustainable city creates a sustainable lifestyle in four areas: ecology, economics, politics and culture. The relationship between lifestyle and health is most fully expressed in the concept of "healthy lifestyle" - it is a prerequisite for the development of various aspects of human life, the achievement of active longevity and the full performance of social functions. The integrated development of facilities that form the social infrastructure of the city, their accessibility and effective functioning play an important role in improving the level and quality of life of the population. This is very important for Krasnodar as one of the fastest growing cities with a million-plus population. The working-age population is $58.7 \%$, it is distributed in four intra-city districts extremely unevenly, more than $8 \%$ of the population lives in rural settlements that are part of the Krasnodar municipality. The rapid growth of the city's population, on the one hand, creates an increased burden on the social infrastructure, and on the other hand, it is the key to the successful socioeconomic development of the city. Krasnodar belongs to the category "City with a favorable urban environment". However, there remains an urgent need for preschool and secondary education organizations, as well as medical organizations. One of the ways to solve these problems is Krasnodar's entry into the Healthy Cities network. Urban health initiatives, developed under the auspices of WHO, are driving change to create urban health and urban environments that will help improve the health and well-being of people.
\end{abstract}

Keywords: world health organization, healthy lifestyle, healthy city, innovation, social infrastructure, sustainable city, human capital.

\section{INTRODUCTION}

Despite the fact that the term "sustainable city" "Sustainable city" or "Ecocity" appeared more than 30 years ago, there is still no fully agreed definition. Living in it leads to the rational consumption of natural resources, the use of environmentally friendly materials, reduced energy consumption and care for the environment. Life in a healthy city is impossible without a healthy lifestyle. In turn, a healthy lifestyle is an indispensable condition for human health and the reproduction of human capital. The life expectancy of each person and the structure of the population of a sustainable city as a whole depend on it. There is a great relationship between the incidence and lifestyle of a person. The social infrastructure of the city combines housing and communal services, healthcare, education, culture and art, physical education and sports, trade and public catering, and consumer services. The development and effective functioning of facilities included in the social infrastructure, their accessibility is an important condition for improving the level and quality of life of the country's population. $[1,2,3]$

The health culture of each individual and society as a whole is of great importance. It is important for society to finally realize that the highest value of human life is health, which must be taken care of. In those countries where this awareness has already come, there are high health indicators and a long life expectancy. So, according to various world rankings, such as the World Health Organization's Ranking of the World's Health Systems, Global Health Index (Bloomberg) and others, the countries in which, according to WHO experts, the health system as a set of all organizations, institutions and resources, has the main goal of improving health, and the ultimate responsibility for its overall functioning in the country rests with the government, but sound leadership 
in districts, municipalities and individual medical institutions is also very important. [5]

\section{MATERIALS AND METHODS}

The social infrastructure of a city is a system of objects, communications necessary for human life support, as well as enterprises, institutions and organizations that provide social and communal services to the population, government bodies and personnel, whose activities are aimed at meeting the social needs of citizens that correspond to the established indicators of the quality of life

At the municipal level, social services are delivered directly to the consumer. At the federal level and at the level of the subjects of the federation, conditions are created for their implementation. The functions of the social infrastructure are determined and subordinated to the goals of social and economic development of society - the achievement of social homogeneity of society and the all-round harmonious development of the individual.
The main purpose of the functioning of social infrastructure facilities is the full and all-round development of a person's personality by satisfying his everyday, spiritual and cultural needs, and the functions of social infrastructure themselves fully correlate with the Ecocity paradigm.

The social infrastructure of the municipality is characterized by the presence of several sources of financing: tax payments, subsidies, loans, funds of entrepreneurs. Competent use of these budgets implies a high level of economic, economic policy, strategic vision. The municipal authorities are responsible for this. [6]

According to experts, today $55 \%$ of the world's population lives in cities and urban areas and by 2050 this number will increase to $70 \%$. In this regard, there are clear advantages for further defining and working towards the goals of sustainable cities. People are social by nature and need urban spaces that foster social connections. [1]

Table 1. Indicators of the natural movement of the population of the Krasnodar Territory.

\begin{tabular}{|l|l|l|l|l|l|}
\hline \multirow{2}{*}{} & \multicolumn{3}{l}{ January-June } & \multicolumn{2}{l}{ per 1000 population } \\
\cline { 2 - 7 } & \multicolumn{2}{l}{ human } & \multicolumn{2}{l|}{} \\
\cline { 2 - 7 } & 2021 & 2020 & dynamics, abs. & 2021 & 2020 \\
\hline Births & 28244 & 27261 & +983 & 10,0 & 9,7 \\
\hline Die & 44012 & 35513 & +8499 & 15,6 & 12,6 \\
\hline including children under 1 year old & 106 & 107 & -1 & 3,6 & 3,5 \\
\hline Natural increase (+), decrease (-) & -15768 & -8252 & & $-5,6$ & $-2,9$ \\
\hline Marriages & 16968 & 11541 & +5427 & 6,0 & 4,1 \\
\hline Divorces & 13253 & 9080 & +4173 & 4,7 & 3,2 \\
\hline
\end{tabular}

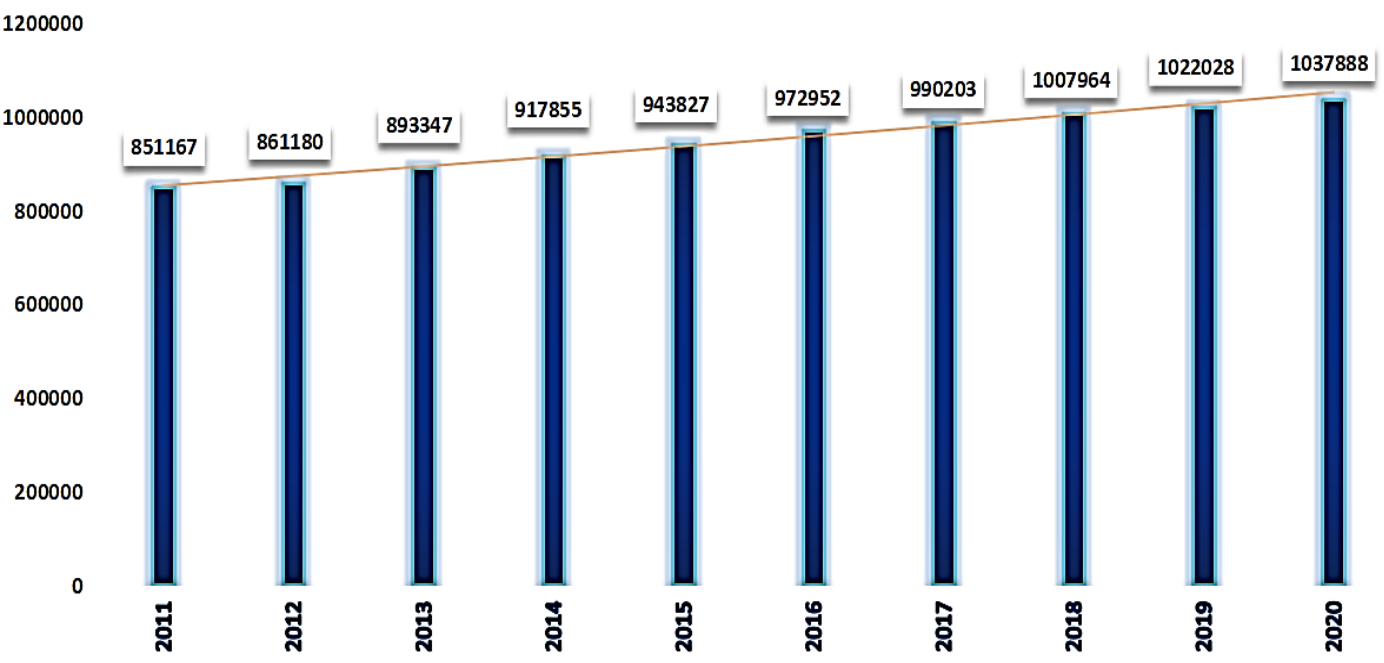

Figure 1 Population of Krasnodar in 2011-2020 Source: Krasnodarstat. 


\section{RESULTS AND DISCUSSION}

According to the State Statistics Service, the resident population of the Krasnodar Territory as of July 1, 2021. amounted to 5686.0 thousand people. The socioeconomic characteristics of the Krasnodar Territory (the agricultural sector is developed) determine the specifics of the structure of the population: the number of urban residents is $11.4 \%$ higher than the rural population: 3169.2 thousand people $(55.7 \%)$ - urban dwellers and 2516.8 thousand people $(44.3 \%)$ - rural residents. In general, in the region in January-June 2021. the number of deaths exceeded the number of births by 1.6 times (Table 1). At the same time, it cannot be said that doctors working in cities serve exclusively the urban population - in the region there is a developed structure of medical organizations, including a significant number of specialized regional hospitals, including in the territory of the city of Krasnodar. There is also a shortage of medical workers in the Krasnodar Territory - there are not enough more than 7 thousand doctors and more than 9 thousand mid-level health workers. [10]

Krasnodar is one of the fastest growing megalopolises in Russia, but its growth rate has slowed down in recent years. If in 2013-2016. the population of the city increased by an average of 28 thousand people or $3 \%$ per year, then in 2017-2020. - for 16 thousand people or $1.6 \%$ (Figure 1). In September 2018, Krasnodar officially received the status of the 16th city with a population of over one million. As of January 1, 2021, the population of the Krasnodar municipal district was 1,037,888 people. The territory of the municipality of Krasnodar is 841.4 sq. Km. Population density - 3217.37 people / km² .

In the structure of the population of Krasnodar, women predominate $-54.8 \%$ (569046 people). At the same time, there are more women both among the urban $55.1 \%$ (522952 people) and among the rural population living in the territories of the municipal district of Krasnodar $51.7 \%$ (46,094 people). The working-age population is $58.7 \%$ of the city's population. The number of women of working age also predominates (Table 2).
According to the concept formulated by the International Labor Organization, social security contains the following elements: stimulation of a stable, paid work activity; prevention of social risks and compensation of income through social insurance mechanisms; provision of social assistance to vulnerable groups of the population that are not participants in the insurance system; ensuring citizens' access to education and health care. [11]

In the changing socio-economic conditions, the number of funding sources has sharply increased, as the commercialization of social infrastructure has intensified. But still the main volume of expenditures falls on local budgets. The powers of local governments include organizing the provision of emergency medical care, organizing the provision of education, creating conditions for organizing mass recreation and leisure, public services, organizing funeral services and maintaining burial sites. Social support, vocational education, the organization of specialized health care institutions and the development of culture are within the competence of the constituent entities of the Russian Federation. [6, 12]

The territory of the Moscow region of Krasnodar includes 4 intracity districts (Figure 2): Zapadniy, Karasunskiy, Prikubanskiy and Centralniy.

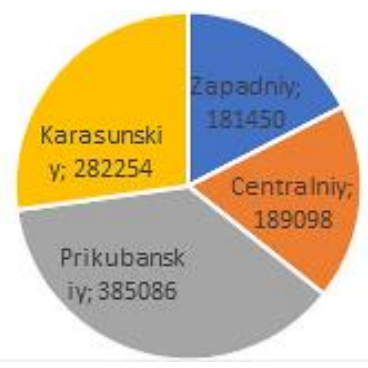

Figure 2 Population of the Moscow region of Krasnodar (by districts) in 2020, people

The population of Krasnodar is distributed extremely unevenly across the four inner-city districts. Most of the

Table 2. Age and sex composition of the population of the Moscow region of Krasnodar Territory as of January 1, 2021.

\begin{tabular}{|l|c|c|c|c|c|c|c|c|c|}
\hline \multirow{2}{*}{ Age (years) } & \multicolumn{3}{c|}{ All population } & \multicolumn{3}{c|}{ Urban population } & \multicolumn{3}{c|}{ Rural population } \\
\cline { 2 - 10 } & $\begin{array}{l}\text { men and } \\
\text { women }\end{array}$ & men & women & $\begin{array}{c}\text { men and } \\
\text { women }\end{array}$ & men & women & $\begin{array}{c}\text { men and } \\
\text { women }\end{array}$ & men & women \\
\hline All population & 1037888 & 468842 & 569046 & 948827 & 425875 & 522952 & 89061 & 42967 & 46094 \\
\hline $\begin{array}{l}\text { Younger than } \\
\text { working age }\end{array}$ & 202735 & 103952 & 98783 & 190357 & 97632 & 92725 & 12378 & 6320 & 6058 \\
\hline Of working age & 608812 & 298694 & 310118 & 557377 & 270789 & 286588 & 51435 & 27905 & 23530 \\
\hline Over working age & 226341 & 66196 & 160145 & 201093 & 57454 & 143639 & 25248 & 8742 & 16506 \\
\hline
\end{tabular}


citizens live in the overcrowded Prikubanskie (37.1\%) and Karasunskiy districts $(27.2 \%)$, experiencing significant inconveniences in terms of access to social services and infrastructure. Another 89,061 people. $(8.6 \%)$ live in 29 rural settlements included in the Krasnodar municipality (Figure 3).

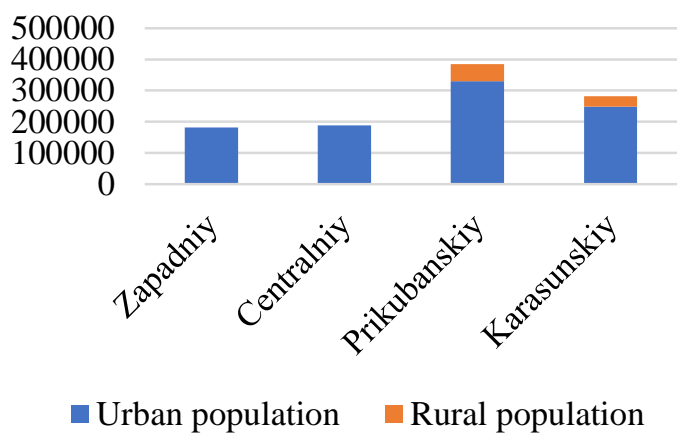

Figure 3 Population structure of the municipal district of Krasnodar (by districts) in 2020, people

The social infrastructure reproduces and develops the main wealth of the municipality - its human potential, human capital. The maintenance and development of the social infrastructure of the municipality absorbs a significant share of local budget funds (Figure 4). Most of the so-called state employees work in the social infrastructure sectors, i.e. workers whose wages are paid from the local budget. [9, 11, 13, 14]

Some of the problems are solved through interbudgetary subsidies and subventions, and some through interaction between government and business. Funding of socially-oriented expenditures is carried out as a priority (Figure 5).

The share of expenses for these purposes in the total amount of expenses amounted to $60.7 \%$. The reduction in funding for the Healthcare industry occurred due to the transfer from 01.01.2019 of healthcare institutions to the state ownership of the Krasnodar Territory, as well as a slight decrease in social spending in 2020 compared to 2019 by 12.7 million rubles. or $0.95 \%$. Particular attention is paid to ensuring an increase in the average wages of certain categories of workers, determined by the May decrees of the President of the Russian Federation.

In January-February 2021, positive dynamics persisted in most macroeconomic indicators of the socioeconomic development of the municipality of the city of Krasnodar in terms of large and medium-sized enterprises.

The indicators of the city's consumer sphere development are characterized by an increase in retail trade turnover in comparable prices - by $0.6 \%$, public catering turnover - by 1.5 times, the volume of paid services to the population - by 1.5 times.
According to the operative statistical data at the end of 2020, out of 16 indicators of the indicative plan for the socio-economic development of the Krasnodar Region for 2020, the planned values were achieved for 9 indicators.

In a relatively short period of time, the city has made a big leap forward in its development, however, population growth and high rates of housing development have led to the fact that the most costly elements of the urban environment, transport network and social sphere cannot cope with the increased load on them, and the city is experiencing lack of financial resources. At present, it turns out that a number of problems can be solved thanks to the implementation of the Priority National Projects.

Thanks to the Housing and Urban Environment national project, the construction of socially significant objects is receiving additional support: schools, kindergartens, medical institutions, highways are being built in new residential neighborhoods, as well as engineering communications. These measures are implemented by the Stimulus program. In 2021, the construction of socially significant facilities will receive additional support from the federal budget.

The Government of the Russian Federation decided to expand opportunities for regions to receive support for the construction of social infrastructure facilities - a preferential loan has been developed for a period of up to 3 years at a rate of no more than $3 \%$ per annum for builders of social facilities - it implies that organizations involved in the construction of engineering, social and transport infrastructures implemented with the involvement of federal budget funds will be able to obtain loans from Russian banks for the early execution of government contracts.

One of the key objectives of the national project is to improve the comfort of the urban environment. By 2030, the quality of the urban environment should be improved 1.5 times and the share of cities with a favorable urban environment increased to $80 \%$.

Today there are 185 municipal preschool educational organizations and 108 municipal educational organizations. During the period from 2019 to 2020, 9 schools and 15 kindergartens were built. But these measures did not meet the needs of the municipality of Krasnodar. In schools, the educational process is carried out in two shifts (in the strategy of the Russian Federation there is a task, education in schools in one shift).

Currently, new facilities are being built, buildings are being completed for existing schools, and reconstruction is being carried out in 5 more kindergartens that have been returned to municipal ownership. 


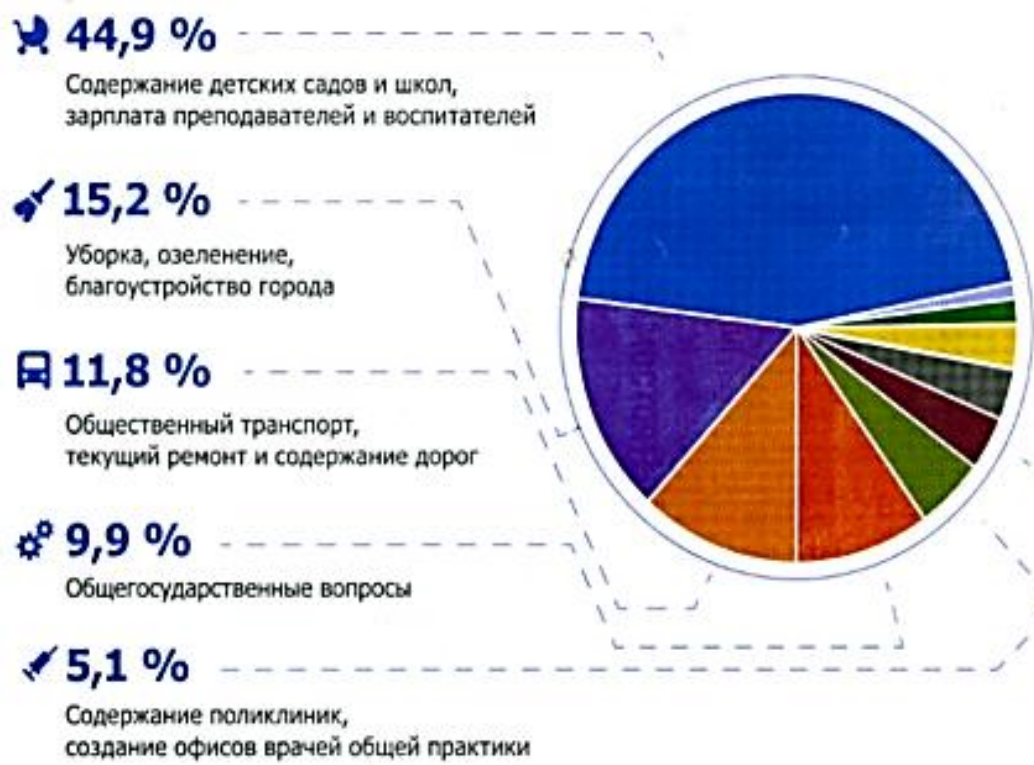

$1,1 \%$

Физхультура и спорт

$1,7 \%$

rO $\mathrm{n} 4 \mathrm{C}$

\section{],1\%}

Содержание домов культуры, клубов, библиотек, шкал искуеств

\section{正 3,5\%}

Прочне расходы

\section{i. $3,7 \%$}

Предоставление

социальных выплат и лыгот

Figure 4. The structure of budget expenditures of the Ministry of Defense of Krasnodar, where: Содержание детских садов и школ, зарплата преподавателей и воспитателей - Maintenance of kindergartens and schools, salaries of teachers and educators, Уборка, озеленение, благоустройство города - Cleaning, gardening, city improvement, общественный транспорт, текущий ремонт и содержание дорог - public transport, maintenance and road maintenance, общегосударственные вопросы - national issues, содержание поликлиник, создание офисов врачей общей практики - maintenance of polyclinics, creation of offices of general practitioners, физкультура и спорт - physical education and sports, ГО и ЧС - civil defense and emergencies, содержание домов культуры, клубов, библиотек, школ искусств - maintenance of houses of culture, clubs, libraries, art schools, прочие расходы - other expenses, предоставление социальных выплат и льгот - provision of social benefits and benefits.

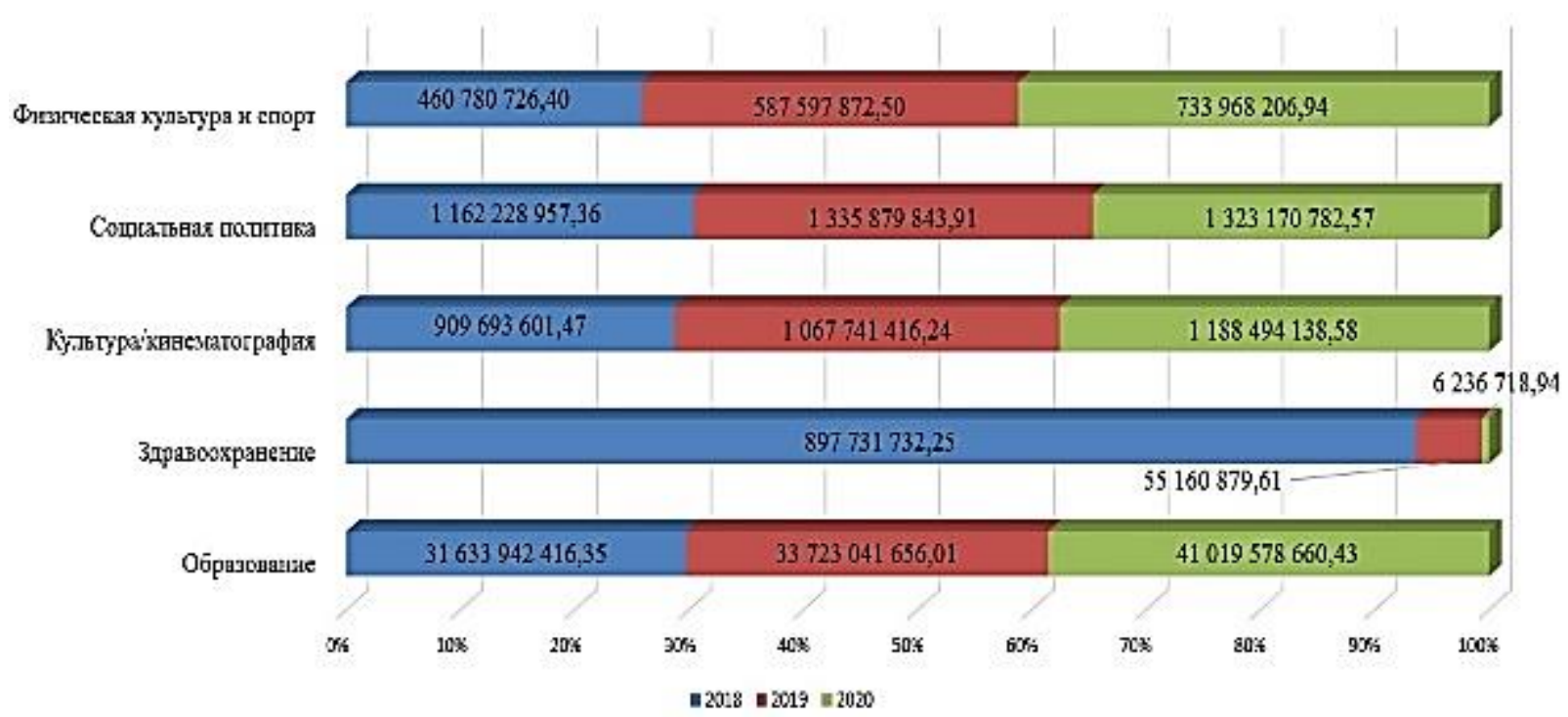

Figure 5 Dynamics and volumes of expenditures of the budget of the Ministry of Defense of Krasnodar for the social sphere, where: физическая культура и спорт - physical Culture and sport, Социальная политика - Soсіаl politics, культура/кинематография - culture / cinematography, Здравоохранение - Health care, образование education. 
Program "Development of Education in the Municipal Formation of the City of Krasnodar" is being implemented worth 14,241.5 million rubles. Expenditures on education are the largest item (36.8\%) in the city budget, this is even more than expenditures on housing and communal services. This situation is quite typical for regional centers. However, it is impossible to count on the transition of Krasnodar education to a qualitatively new level only at the expense of budget funds.

In addition to education, the social sphere includes culture and cinema. 1637.6 million rubles were allocated for the activities of the municipal program "Development of Culture in the Municipal Formation of the City of Krasnodar". (development of houses of culture, creative associations, libraries, art organizations).

Another type of social sphere is physical culture and sports. Much attention is paid to this area of the social sphere and the formation of its infrastructure facilities, because not only the development of sports in the country depends on their condition, but also the maintenance of the health of the population. In the municipal district of Krasnodar, measures of the municipal program "Development of physical culture and sports in the municipal formation of the city of Krasnodar" are being implemented - 792.9 million rubles. ( 9 sports schools, a sports club for disabled people "Iskra", the Center for physical culture and mass work, the Sports Palace "Olymp"), construction and reconstruction of sports facilities is being carried out (including including the reconstruction of a sports complex with a swimming pool). The active construction of sports facilities on the territory of the city is associated with the growth of all the main indicators of the development of physical culture In $2018,46.1 \%$ of the total population of the city were systematically engaged in physical culture and sports (in 2006 - only 12.1\%).

The main problems of the Krasnodar municipal district: deficit in healthcare facilities - $60 \%$, education $40 \%$, culture $-50 \%$, sports - $20 \%$, mainly in places of dense complex development; a sharp increase in the population, outstripping the growth rate of social infrastructure; insufficient financial resources to ensure the creation of social infrastructure facilities; low involvement of business in the creation of social infrastructure facilities.

One of the ways to solve these problems is Krasnodar's entry into the Healthy Cities network. Aligned with global and regional strategies, Healthy Cities is strategically positioned to continue to highlight and promote the important role that local governments play in improving health and well-being in a participatory approach and the whole society.

\section{CONCLUSION}

The increase in demand for services from social infrastructure facilities largely depends on housing plans, which in turn must be consistent with the concept of a sustainable city.

The importance of social infrastructure is determined by its impact on the entire process of social reproduction: product, labor force, labor productivity, cultural life of society, improvement of working and living conditions. The social infrastructure reproduces and develops the main wealth of the municipality - its human potential, human capital.

Today the city of Krasnodar is constantly growing, which in turn leads to an uneven distribution of social infrastructure facilities. On the territory of the city, large residential areas have been laid, not provided with new medical institutions and educational organizations. Despite all the measures taken (improvement and repair of facilities, construction of new ones), there is an urgent need for preschool places in the social infrastructure of the city. In connection with the low rates of construction of general education schools, there has been a steady trend towards an increase in the proportion of students studying in the second shift.

It is necessary to introduce the practice of burdening developers with the obligations of building premises for the placement of multidisciplinary clinics, which will serve the residents of the built-up microdistricts.

The social infrastructure of a municipality is an association of economic sectors whose activities are aimed at creating and offering social services to the population and fulfilling social obligations.

\section{REFERENCES}

[1] E.A. Sertakova, Research «city» in the classical concepts of the foreign scientists. Modern Problems of Science and Education. Surgery 4 (2013) p. 381.

[2] S. Mukhametdinova, E. Tyumentseva, O. Patlasov, O. Luchko, Designing the reference architecture of human ecology on the basis of the methodology of the function oriented modelling, In: E3S Web of Conferences, 2021, p. 02016. DOI: https://doi.org/10.1051/shsconf/202110102016.

[3] T. Moiseeva, Y. Myatishkin, Innovative development of socio-technical systems, In: E3S Web of Conferences, 2021, 02022. DOI: https://doi.org/10.1051/shsconf/202110102022.

[4] S.T. Kohan, A.V. Pateyuk, E.M. Krivosheeva, The basics of a healthy lifestyle. ZabGU 2015 p. 185.

[5] R. Lozano Measuring performance on the Healthcare Access and Quality Index for 195 countries and territories and selected subnational locations: a 
systematic analysis from the Global Burden of Disease Study 2016.

[6] The Lancet 391 (2018) pp. 2236-2271. DOI: https://doi.org/10.1016/S0140-6736(18)30994-2.

[7] V.V. Smirnov, V.L. Semenov, A.N. Zakharova, S.B. Zimin, A.V. Mulendeeva, Modeling the coherence of the financial system and economy of Russia, In: E3S Web of Conferences, 2021, p. 02007. DOI: https://doi.org/10.1051/shsconf/202110102007.

[8] R. Sarbu, C. Alpopi, S. Burlacu, S. Diaconu, Sustainable Urban Development in the Context of Globalization and the Health Crisis Caused by the Covid-19 Pandemic, In: SHS Web of Conferences, 2021, p. 01043. DOI: https://doi.org/10.1051/shsco $\mathrm{nf} / 20219201043$.

[9] V. M. Dumitrache, S. Platagea Gombos, F.Bran, P.E. Balu, The dynamics of human capital accumulation in the ex-communist countries in Europe in the context of globalization, In: SHS Web of Conferences, 2021, p. 02014. DOI: https://doi.org/10.1051/shsconf/20219202014.

[10] I. Ershova, ISolodiankina, Regional human capital development management in the process of globalization, In: SHS Web of Conferences, 2021, p. 02017. DOI: https://doi.org/10.1051/shsconf/20219 202017.

[11] E. Chernenko, I. Lebedeva, Personnel imbalance and ways to overcome it in the healthcare sector, In: E3S Web of Conferences, 2021, p. 02025. DOI: https://doi.org/10.1051/shsconf/202110102025.

[12] M. Masca, Evaluation of human capital performance of the countries by CRITIC and COPRAS methods: an application on the members of the organization of the black sea economic cooperation, In: SHS Web of Conferences, 2021, p. 01003. DOI: https://doi.org/10.1051/shsconf/202112001003.

[13] O. Ponisciakova, Knowledge management and its application in human resources management in the context of globalization, In: SHS Web of Conferences, 2020, p. 01026. DOI: https://doi.org/10.1051/shsconf/20207401026.

[14] J. Pechová, Personnel trends in a globalised world, In: SHS Web of Conferences, 2020, p. 202001024. DOI: https://doi.org/10.1051/shsconf/20207401024.

[15] E. Kicová, Specifics of human resources in nonprofit organizations in the process of globalization, In: SHS Web of Conferences, 2020, p, 01011. DOI: https://doi.org/10.1051/shsconf/20207401011.

[16] N.A. Avxentyev, V.S. Nazarov, N.N. Sisigina, How could we improve the national projects in health and demography after coronavirus pandemic? Economic issues 6 (2020) pp. 22-36.
[17] L.S. Koval'zhina, The concept of "Healthy Cities" and health-saving behavior of urban population: sociological analysis. Contents of Issue 01 (2020) pp. 1-10. DOI: https://doi.org/10.7256/23108673.2020.1.31864.

[18] WHO European Healthy Cities Network. Regional office for Europe 2021.https://www.euro.who.int/en /health-topics/environment-and-health/urbanhealth/who-european-healthy-cities-network

[19] Compendium of tools, resources and networks on Place: WHO European Healthy Cities Network Phase VII Support Package for Implementation (2020). World Health Organization Regional Office for Europe 2020 p. 44. 